\title{
Rgvedic Poetic Art: The Language of Literature
}

\author{
Bibhudatta Dash \\ Assistant Professor, Department of Humanities \& Social Sciences, Visvesvaraya National \\ Institute of Technology, Nagpur, India. ORCID: oooo-0oo2-3880-4739. \\ Email:dr.bibhudattadash@gmail.com
}

\begin{abstract}
This article explores Rgveda and traces the genesis of poetics by interpreting various Rgvedic mantras (sacred utterances) to find out the figures of sound and sense; language of metaphors; linguistic constructs; language of suggestion and aesthetic enjoyment. It shows how Sanskrit rhetoricians were inspired and influenced by the Rgveda and how they succeeded in developing theoretical perspectives of literary art from this original source of art, poetry, and criticism. This research also intends to discuss how the Vedic poet-seers discovered the language of literature in the absence of a formal text on poetics and aims to understand how the literary communications are different from ordinary communications.
\end{abstract}

Keywords: Rgveda, Poetics, Sound, Sense, Suggestion, Language, Aesthetics, Metaphor

\section{Introduction}

Literary studies developed on the triple ground works of grammar, metrics and criticism. The terminology for criticism in Sanskrit is either Sāhityaśāstra or Alaṁkāraśāstra. Sāhitya emphasizes on the appropriate unity of form and content in literature and alamkāra points out to the beautiful aspect of it. Criticism is the unique way of expounding the principles of the nature of poetry and its composition. The aesthetic principle of any literary genre also comes under its domain. Any literary discourse $(k \bar{a} v y a)$ is different from an ordinary communication (vārtā) since in the kāaya the potency of the language conveys powerful human emotions successfully. The Sanskrit rhetoricians like Kavirāja (16) equated poetry with a human being (Kāvyapuruṣa) where words and meaning (śabdärthau) constitute the body. However, their search for the soul was speculative for which they succeeded in developing various theoretical schools like the school of alamkāra, guna, rìti, rasa, dhvani etc. Since the Rgveda is the source of poetic wisdom, investigation for the theoretical perspectives of various literary discourses are conducted through this original source of great poetic utterances.

\section{Rgveda: the Genesis of Poetry and Poetics}

Upanișads, the end part of each of the Vedas, speak of the Brahman (the Absolute) as sat, cit, and ananda which gives philosophic interpretation of the universe. Sat as such refers to existence, metaphysics, and ethics; cit refers to consciousness, knowledge, thought and reality; but the concept of ànanda belongs to the realm of beauty of aesthetics. This triune unity of saccidananda or satya, siva, sundara (truth, good, and beauty) constitute the higher experiences or the

(C) AesthetixMS 2020. This Open Access article is published under a Creative Commons Attribution Non-Commercial 4.0 International License (http://creativecommons.org/licenses/by-nc/4.0/), which permits non-commercial re-use, distribution, and reproduction in any medium, provided the original work is properly cited. For citation use the DOI. For commercial re-use, please contact editor@rupkatha.com. 
experiences of the Absolute/Brahman (Sastri, 1998: 338). The Taittiriya Upanișad (3.10.5) belonging to Yajurveda says that blissful aspect of the Brahman reveals itself in sammagāna (singing of the chants) (Radhakrishnan, 2012: 561)

Gāna (music) - a unit of the fine arts and poetry is all inclusive. Therefore, the basic metre in the Rgveda is named as Gāyatrī which means that it protects the singer - gāantam trāyate (Apte, 2007: 343). Out of all the mantras the Gāyatri-mantra is considered very sacred and important. It is said that great sins are even expiated by repetition of this mantra: om bhürbhuvah svah tacchaviturvarenyam bhargo devasya dhïmahī dhīyo yo nặ pracodayāt (Rgveda, 3.62.10). Its importance is further noted when lord Krișna in the Bhagavadgitā, 10.35 proclaims that "I am Gāyatrī among the Vedic metres - "gāyatri chandasāmaham". This reveals that to the Vedic seers rhythm, melody and harmony are the basic principles of poetry.

For all time to come Rgvedic seers have offered the principles of interpretation of the creative genious in a famous mantra as follows:

devānām nu vayaṁ jānā pravocāma vipanyayāuktheșu śaśyamāneșu yaḥpaśyāduttare yuge. (Rgveda, 10.72.1).

In this mantra the Vedic seer addresses his fellow singers to sing sweetly the merits of generations of Gods, so that one can perceive their presence at the time of the incantation of these hymns in a future age. According to Sāyanan, the Vedic critic, the subject of the whole hymn (Rgveda, 10.72) is devoted to the Gods as the eulogy of the understanding of the Vedas is essential to divine knowledge (Griffith, 2004: 585). This suggests that poetry must include divine feelings so that divinity can be attracted by chanting the same at any other point of time. The sweet singing suggests that the language of poetry should be full of rhythmic effect. This hints at the metrical or melodious effect of the lines which are free from blemishes that deter the effective attention of the audiences. It is possible only when there is happy marriage of sound and sense in a composition.

In the latter classical period Bhāmaha $\left(7^{\text {th }} \mathrm{AD}\right)$ was inspired to give the definition of the kāvya as śabdārthau sahitau kāvyam (1.16) which means, word and meaning taken together constitute kāvya. In the same way Rudrața (1990) says: "nanu śabdārthau kāryam" (II.I) which means, sound and sense constitute a kārya. In this context Mammața (2005) defined that poetry is fault-free word and sense which abound in merit and excellences of style. It, at times, may be without figures of speech- "tadadoșau śabdārthau sagunāvanalamkrtī punaḥ kvā'pi”. (1.4). The Veda has suggested that the description should be such that it can enliven the past and can have paramount effect on the future audience. In the Rgveda the seers fully realize the importance of speech which fulfils both material and spiritual desire of the invoker:

ahaṁrāṣtrī saṁgamanī vasūnaṁ cikituṣī prathamā yajñiyānām I

tāmādevāvyadadhuḥ purutrā bhūristhātrāì bhūryāveśayantīm II

ahameva svayamidaṁ vadāmi juștam devebhiruta mānuṣebhị I

yam் kāmaye taṁtamugram் kṛnomi tam் brāhmaṇam் tamrṣim tam் sumedhām II

(Rgveda, X.125.3\&5).

Here speech presents herself as the Queen of earth who offers abundance of wealth to the devotees. She (Speech) is the repository of wisdom and first among those who deserve to be worshiped in the Yajna (ritual sacrifice).Gods have stationed her at different places and different beings, and thus she (Speech) has universal presence. She (Speech) herself utters and announces such adorable wisdom (the Supreme Soul or Brahman) to which both humans and Gods welcome. Whomsoever 
she (Speech) likes makes him/her exceedingly powerful, a creator, a seer or a person of wisdom. In this context of literary speech, one comes across metres, rhymes, rhythmical utterances, alamkāra (decorative devices) and rasa (aesthetic enjoyment) at different points of description. Besides, the figures of sense and sound contribute enormously to the growth of the language of Rgvedic literature which is illustrated in the following unit.

\section{Rgveda and Figurative Language: the Figures of Sound and Sense}

Alamikāraśāstra developed as a separate branch of study during $7^{\text {th }}$ century AD and the rhetoricians started giving definitions of different figures of speech which were greatly influenced by the Rgvedic utterances. Such definition of the later period are noted with examples of their application in some mantras.

The Sāhityadarpana (10.14) defines Upamā (Simile) as the primary figure of sense which presents the resemblance between two things (subject of description and object of comparison) expressed in a single sentence and un-occupied with the statement of difference. The simile is fully expressed (Purnopamā) when the subject of description, the object of comparison, the common property, the words implying comparison, are fully expressed in a single sentence (Kane, 1995: 8990). One Rgvedic mantra is noted for analysis as follows:

davidhvato raśmayaḥ sūryasya carmevā vādhustamo apsvantặ (Rgveda, 4.13.4) which means, the tremulous rays of the sun cause the hide like darkness to sink (get eliminated) in the sky. Here in the sentence of the above mantra 'sūryasya raśmayah' is the subject and 'avadhuh' is the verb, tamas is the subject of description, carma (skin) is the object of comparison, the word iva implies denotation. The common property (sādhäranadharma) of both tamas (darkness) and carma (skin) is tìraskärayogyatā (deserving condemnation or rejection) which is not expressed and is suggested by the verb avādhuh. So this becomes an instance of Luptopamā (elliptical simile). Upamā becomes direct (śrautī) in which the notion of comparison is conveyed by particles, such as yathā, $i v a, v \bar{a}$ or by the affix vat when it is equivalent to iva. This becomes Indirect (a $r$ rthī) when the notion of comparison is conveyed by the attributive words like tulya, samāna or by affix vat when used in the sense of tulya (equal). With regard to the above definition the description in the context is an instance of śrautī upamā.

Mālopamā (Garland of Similes) - when several upamānas (objects of comparison) enrich the description in connection with one Upameya (subject of description), then it is known as Garland of similies (Kavirāja, 1977: 10.26). Novel use of such similes in the Rgveda, may be observed as follows:

abhrāteva puṁsa eti pratīcī gartārugiva sanaye dhanānām I

jāyevapatya uśatī suvāsā uṣā hasreva niriṇite apsaḥ II (1.124.7)

This is the description of Dawn (Ușas). She is described as a brotherless woman. Mounting her car she moves from her place (Pratīcī) to the men (Piträdin-parents etc.) as if for gathering riches. She like a beloved wife to her husband, smiling and well dressed, lays bare her beauty instantly. Here a crescendo of similitudes mark the description. Here $u s ̦ \bar{a}$, the subject of description is compared to several objects of comparisons like, abhräteva (like a lady with no brother), gartärugiva (like a lady mounting her car) jāyeva (like a loving matron), and harseva (like a smiling lady) and hence this is an instance of mālopamā. Another such instance is also noted in the description of Savitā as follows:

gāva iva grāmam் yūyudhirivāśvānvāśreva vatsam sumanā duhānā I 
patiriva jāyāmabhino nyetu dhartādivaḥ savitā viśvavārah II (Rgveda 10.149.4)

Savita is the lord of blessings and the bearer of heaven who is prayed to come down to the worshipers like warriors to their horses, cows to their village, milk giving cows(approaching) their calves, and like men to their wives.

Besides a good number of figures of sense mark the description of the game of Dice in the Rgveda as follows:

nīcāvartanta uparisphurantya hastāso hastavantaì sahante I

divyāañgārā iriṇenyuptaḥ śìtāḥ santo hṛdayaṁ nirdahanti II (Rgveda, 10.34.9)

The dice rolls downwards and swiftly springs upwards. Though handless, they force the hands of man to serve them. Further they are compared to the lumps of magic (divine) charcoal, which though cold themselves, burn the player's heart to ashes. Here one meets the figure of speech Virodha (Contradiction) as the coldness burns the heart (cf. Kavirāja, 1977: 10.68-10.69). Also the same figure of speech is marked in the description of the moving chariot of Agni: nayorupabdiraśvah śrnve rathasya kaccana / yadagne yāsidūtyam (Rgveda, 1.74.7). It means, Lord Agni moves like an emissary of Gods. At the time of his movement the sound of the steeds of his speedy chariot is not heard. Here the chariot and the steeds of Agni are the causes of sound. In spite of the existence of the cause (of sound) there is no hearing. So this becomes an instance of the figure of sense Viśeșokti (Peculiar Allegation) (cf. Kavirāja, 1977: 10.67; Kane, 1995: 237). In this way many other alamkāras developed at a later period are also marked in the Rgvedic mantras like Arthāntaranyāsa (Rgveda, 1.17.9), Kāvyalinga (Rgveda, 2.33.4), Svabhāvokti (Rgveda, 5.83.4), śleșa (Rgveda 4.13.2) etc. (cf. Kane, 2015: 28-29)

With the use of the figures of sounds (śabdālamkāra) the Veda also revealed in the musical aspect of language. It is marked in the repetition of some letters and words in the mantras. The Vedic poets were fond of the repetition of the same letters or words which create an appearance of the figures of sound known as anuprāsa (alliteration) in later times. Anuprāsa is the frequent repetition of the consonants in a description with or without regard to the vowels sounds associated with them - anuprāsaḥ śabdasāmyam vaișamye'pi svarasya yat (Kavirāja, 1977: 10.2). One mantra with alliteration reads: rakșāṇo agne tava rakṣaṇebhī rārakșāṇạ sumakhaprīnānaḥ (Rgveda, 4.3.14). Here one gets the repetition of five ' $r a$ ' letters with addition of vowels at two places, three ' $k s$ ' letters with addition of vowels at two places, and four ' $n a$ ' letters. The mantra pratäryagne prataram na $\bar{a} y u h$ (Rgveda, 4.12.6) exhibits the repetition of 'pra' and ' $t a$ ' twice each where one long vowel 'a' is added with the first 'ta' letter. In the same way the mantra - nrșadvara sadrta sadyo masadabja gojā rtaja adrija rtam (Rgveda, 4.40.5) presents the repetition of the letter ' $j a$ ' successively for four times. Thus, Rgveda is replete with such alliterations.

Rūpaka (Metaphor) as a figure of speech (figure of sense) also has a distinguished place in the description of Vedic mantras which is analysed in the following unit.

\section{Rgveda: the language of Metaphors}

Metaphor (Rūpaka) is a basic figurative literary device where one thing is described in terms of another. In metaphor comparison is implicit unlike simile, where it is explicit. Mammața in his book on poetics the Kāvyaprakāśa explains that in a piece of poetic art where there is non-difference between the object compared to and the subject compared, is known as metaphor. The idea of nondifference is based upon extreme likeness between two objects, the difference of which is not 
entirely concealed. In cases where the subjects imposed upon, as well as the objects imposed are directly mentioned by words, it becomes Universal Metaphor. It gives the sense that the whole (samasta) of what is imposed (nyasta) is its expressed objective (vișaya). In the book A Dictionary of Literary Terms and Literary Theory J.A Cuddon (1998) explains about the linguist Roman Jacobson's study of aphasia (a language disorder due to loss of memory) where he writes that language disorder acts on the two axes of language in different ways so that those suffering from 'continuity disorder' tend to use substitution (i.e. metaphor) and those suffering from 'similarity disorder' tend to use association (i.e. metonymy) (507). Keeping the above theoretical perspectives in view the metaphorical use of the language in the Rgveda is noted for analysis as follows:

rrtena hișmā vṛsabha ścidaktaḥ pumaṁ agniḥ payasā prșțyena I

aspandamāno acaradvayodhā vrșāśukram duduhe prśnirūdhah II (Rgveda, 4.3.10)

This is the prayer to the gods like Agni (fire-god) and Prśni (sun god) which means, Agni, the Bull is sprinkled with clarified butter upon his back. He (Agni) offers food, the source of vitality to the worshippers. Seated together in a single place he (Agni) moves with his lustrous self all around. Prśni the bull, milks the pure water from the udder (udhah) that connotes sky or cloud. In this mantrā the metaphor 'the bull' is directly mentioned for both Agni and Prśni 'like Agni the Bull' \& 'Prșni the Bull' which comes under universal metaphor. However, here the words for bull - vrșabhah and $v r s ̦ \bar{a}$ - in the mantra are interpreted by Sàyaṇa as abhimataphalavarșaka (showering favourable fruits on the worshipper), apām varșaka (showering water by milking the sky) respectively. 'sukram duduhe prșnirudhah' is interpreted that the sun-god (Prśni) milked the udder (udhah) which stands as a metaphor suggesting either the sky or the cloud. This shows that most of the Rgvedic metaphors are drawn from nature.

Hyperbole (Atiśayokti) is a figure of speech (figure of sense) which subscribes to the language of metaphor. According to Mammata (2005) it is a hyperbole "when the object to be described is indicated as swallowed up by the other; when the object to be described is presented as another; when there is an assumption introduced by some term meaning 'if'; and when there is reversal of the normal order of sequence between a cause and its effect” (10.100).

The metaphorical language of Hyperbole (Atiśayokti) is observed in Rgveda as follows:

catvāri śrñgā trayo asya pādā dve śîrșe saptahastāso asya I

tridhābaddho vrșabho roravīti maho devo martyām āviveśa II (Rgveda, 4.58.3)

Which means, he has four horns and three feet, two heads, and seven hands. Bound with a triple bond, the bull roars loudly and the mighty God has entered into the land of mortals.

Various interpretations are attempted on the lines of this mantra. The grammarian Patañjali interprets the visayas or the subjects of description as linguistic like four types of words (nāma, $\bar{a}$ khyāta, upasarga, nipāta), three divisions of time (past, present and future), two characteristics of words (sphota - flash of idea in the mind after utterance of a sound, dhvani - suggestive meaning/idea which supersedes denotation and indication), seven bibhaktis (case-endings), three seats of stoppage (urah-chest, kanțhah-throat, śirșah-head) which are completely swallowed up by the visayins (objects of comparison)like four horns, three feet, two heads, seven hands, three seats of stoppage respectively. The roaring vrșabha (bull) stands here as a metaphor of the articulated language (Patañjali, 1989: 30.33). However, Sāyaṇa interprets this with regard to the symbol of sacrificial imagery where the visayas like four Vedas, three savanas (sacrificial libations), two types of sacrifice (Brahmaudan, Pravargya), seven Vedic metres, three sources of sacrifice (Mantra, Kalpa, Brāhmana) are replaced respectively by the visayins noted above. 
In course of the growth of poetry, the Rgveda gave birth to elusive nature of symbolic poetry, where the language became mystic and metaphorical. One mantra is noted for analysis as follows:

dvādaśa pradhayaścakramekaṁ trīni nabhyāni ka utacciketa I

tasmintsākam triśatānaśan்kavorpitāh șaṣtirna calācalāsaḥ II (Rgveda, 1.164.48).

In this prayer to the Viśvedevas it is described that a single wheel has twelve outer rims with three hubs. Here three hundred and sixty spokes are set together which cannot be loosened. This mantra may have several connotations. The metaphorical use of the language is appropriately interpreted by Griffith. He notes here that the year is the single wheel; the twelve outer rims are the months; three hubs are the three seasons having four months each; and the spokes are the three sixty days of the year (2004: 113).

Thus, apart from understanding the metaphorical use of language as above one also needs to get an understanding of various Rgvedic metaphorical linguistic constructs as depicted in the next unit.

\section{Rgveda: the Metaphorical Linguistic Constructs}

Yãska the most ancient scholar of $7^{\text {th }}$ Century B.C. has offered the linguistic interpretation of the Vedic myths. He was acquainted with the other modes of interpretations like the interpretation of the grammarians, ritualists, legendists, and Naidanas (specialist in primary cause), which developed much before his rise. The most modern scholar in the field is Max Muller who subscribes to Yāska's mode of linguistic interpretation and acknowledges myth as the anthropomorphic observation of nature, cognised by metaphorical language. Ernst Cassirer (1964: 3-4) observes that Max Muller accepted philosophical analysis as a means to reveal the nature of Vedic mythical beings and established a novel way of connection between language and myth. He does not believe that myth is the transformation of history into legend or fable accepted as history; it is in fact something which is conditioned and negotiated by the agency of language and is the product of certain shortcomings which are considered the inherent weakness of language.

Yāska interprets Rgvedic narratives - (itihāsa, ākhyāna, gāthā) not as representation of the external natural events and objects but as the constructs of linguistic metaphors. He notes that the Vedic seers delight in the expression of their perception in metaphorical narratives: rșer drsștārthasya prītir bhavatyākhyāna-samiyuktā (Yāska, 2009: 10.10). This elucidates that a piece of literary communication in a metaphorical discourse does not convey empirically verifiable history. The Vedic narratives, in the present critical vocabulary known as myths, legends etc. deliberately fictionalise the events which are presented through metaphorical modes of expression. Yāska emphasises that words should be derived with regard to their meaning in the context as in every language at times it so happens that words of different origin get expressed in the same form. In Nirukta Yāska explains: the sun is called akūpāra, i.e. unlimited, because it is immeasurable; an ocean too is called akūpāra, i.e. unlimited, because it is boundless; and a tortoise is also called akūpāra, because it does not move in a well (a-kūpā-ara) (Yāska, 2009: 4.17-19).

Yãska observes that in the Brāhmana text the proper nouns are not arbitrarily related to the signifieds. They do not stand for particular individual, but for the actions they perform. Jijn̄āsu explains the above idea as follows: A seer is famous by the name Angirā as he sits near angāra (charcol fire) for performing gārhapatya sacrifice and other ones (Gārhapatyopayitvādināañgāreșu vasatìtyangirāh); one who absorbs the weaknesses for material enjoyments is named as Atri (adanāt bhakșanāt rāgādīnām doṣānāmatrih); one who finds out (khananāt/digs out) various materials 
connected with the meaning of the Vedas is named Vaikhānasah (vividhāni khananāt Vedārthavastūnām Vaikhānasah); a person (seer) deformed by penance (with various austerity measures) is named Virūpah (Vairūpyāt tapas $\bar{a}$ Virūpah); and they are addressed seers (rși) for their exact perception of the objects as they are (yatheitesāmrșin̄âà darśanād rșayaḥ) (Jijn̄āsu, 1945: 22-23).

Max Muller (1872) in his book Chips from a German Workshop subscribing to this view says that this period of the Vedas was the mythopoetic period when every common Aryan word carried a sense of myth. Certain attributes and expressions are the representations of the kind of unconscious poetry, which is perhaps lost in the language. He calls some words of Aryan languages as fossil poetry and for that sense pitā, signifying father etymologically conveys the meaning

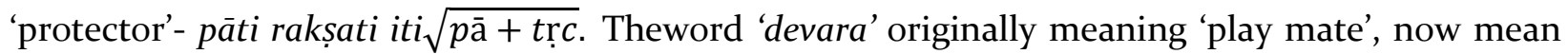
the younger brother of the husband and reveals its own developed story. All the words may not come under this category. However, the importance of the etymological origin of the language cannot be denied. Thus, this way of interpretation of language can be equally applicable to mythology, which is, according to Max Muller, a dialect, an ancient form of language.

The myth of the battle of Indra and Vrtra is famous in the Rgveda. Indra is a great epitome of energy. Indra originates from Indo-European word anro which means man or manly. Vedic critique Güntert equates the name Indra with other epithets like śakra (strong) and tavișa (sturdy) etc. Indra is also derived from the Indo-European oid (swelling) connoting there by swelling virility (Hillebrandt, 1981: 99). Yāska's etymological derivation notes Indra as the offerer of earth, speech, water, flood etc.: irām dṛnātìtivā I irām dadātìt vā I... indau ramata iti vā etc. (Yāska, 2009: 10.8).

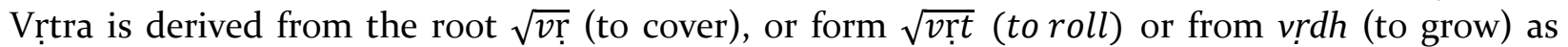
rolling is the characteristic of Vṛtra (Yāska, 2009: 2.17). Yāska notes his derivation of Vṛtra with reference to the Vedic mantra as follows:

\section{atiștantīnāmaniveśanānām kāṣtānāà madhye nihitam śarīram I}

vrtrasya nịyaṁ vicantyāpo dīrghṁ tama āśayadindraśatruh II (Rgveda, 1.32.10)

Etymologists acknowledge Vṛtra as the cloud (megha iti nairuktāh) which flows onwards without rest for ever. The legendists say that it is a demon, the son of Tvaștā (tvāștro'sura ityaitihāsikāhn). The phenomenon of rain gets created by the commingling of water (vapour) and lightening (apām ca jyotișaśca miśrībhāva karmano varșa-karma jāyate). Keeping the above points in view the figurative description of the battle of Vrrtra with Indra is seen (tatropamārthena yuddhvarnā bhavanti). The Brahmana narratives describe him as a serpent as by the expansion of its body it blocked the channels of the rivers. Indra killed Vṛtra and released the closed outlet of water (Yāska, 2009: 2.16).

Thus both Yāska and Max Muller, the ancient and modern seers on Vedic wisdom respectively do prove that Vedic narratives (itihāsa, akhyana, gāthā) are metaphorical linguistic constructs which contributed to the growth of Vedic language and literature. In addition to this the novelty of presentation makes the ancient themes delectable. It is known from the Indra sūkta where the poet sings as follows:

harī nu kaṁ ratha iṁdrasya yojamāyaisūktena vacasā navena I

moṣutvā matra bahavo hi viprā nirīraman yajamānāso anye II (Rgveda, 2.18.3)

Which means, on the way no other worshiper can detain lord Indra, as the horse titled Hari is yoked to the chariot for the speedy movement of the lord to the field of ritual sacrifice which is filled up with numerous new holy singers - suktena vacasā navena. Hence, the mantra signifies that that 
musical aspect of poetry becomes more powerful with novelty of presentation and draws the attention of the readers.

In an invocation to Aśvins (Rgveda, 10.39.2) the poet sings that the twin Gods may be pleased to inspire all pleasant strains for the spontaneous flow of the hymns and for the inspiration of the wisdom with glorious heritage and enjoyment. It shows that the life should be presented in such novel and mellifluous lines that the literature should be both interpretation and criticism of life. In this way the Rgveda presents that a poem is neither a well enveloped idea nor an intellectual excess that leads one to philosophy. Also, it may not be always a mystic and religious consciousness. Never the less it must work like a connecting bridge between the fact and fiction that refines emotions and perfects perception.

\section{Rgveda: Language of Suggestion and Aesthetic Enjoyment}

The origin of development of language lies in the Prätiśākhyas, (the oldest textbooks of the exegetical Vedānga called śikșā), the Padapātha (the text in which all euphonic combinations are resolved into original and separate words), and the dhvani-system (sound patterns - pronunciation, accentuation, euphonic changes) of the language as depicted in the Rgveda. The language further developed in the Brähmana literature of Rgveda which is mostly the prose treatment of the Vedic mantras and the collection of the utterances and discourses of priests on the science of sacrifices. The readers meet here only occasional verses which are of two kinds i.e. gāthā (epic song) and narāśamsi (songs in praise of heroes). The content of the Brāhmaṇa literature is threefold - Vidhi (sacrificial directions), Arthavāda (explanation of the meaning and the purpose of sacrificial works), Upanișad (exegetical, mythological, polemical, theological, or philosophical speculations). However, the earliest meaning of the Brähmana in the Rgveda was 'sublime language' which is connected with the God Brhaspati and two Goddesses - Vāk and Sarasvatì. According to Frits Staal, 'Speech' is the traditionally accepted translation of both Vāk and Brāhmana which refer to the language itself (2008: 291).

This leads us to understand the suggestive nature of language. The words in a language are capable of conveying three-fold senses known as abhidhā (denoted sense), laksanā (indicated sense), and vyañjanā (suggested sense). Three kinds of functions of words which unfold above three senses are termed as vācaka (denotative), lākșaṇika (indicative), vyañjaka (suggestive) respectively (Kavirāja, 1977: 2.3). Primary meaning ( $v \bar{a} c y a)$ is the conventional meaning through the accepted use of the people. The indicated (laksya) is an extended meaning. When the primary sense in a given context is inapplicable, a second sense connected with the primary sense comes out due to popular use (rūdhi) or special purpose (prayojanā). The popularly quoted phrase gangāyām ghoșah (a small village of cow-herds in the Ganges) (Kavirāja, 1977: 2.5) may be considered as an example. As a small village is not possible in the river-stream, the primary sense becomes inoperative. Now the secondary sense is the indicated sense i.e. the bank of the Ganges (river) which comes connected with the primary sense. The purpose behind resorting to indication is to emphasise the quality such as coolness and sanctity of the place due to its proximity with the river Ganges. The purpose itself is the suggested sense which is realised over and above the indicated sense.

When in a poetic composition the suggested sense far excels there primary and secondary sense it becomes dhvanikāvya or poetry of suggestion - vācyātisayini vyañgye dhvanistat kāvyamuttamam (Kavirāja, 1977: 4.1). The above theory of the Sanskrit rhetoricians are suggested in a Rgvedic mantra found in the Jñannasūkta which clearly depicts the distinction between ordinary 
language and the language of poetry. It pays homage to the Vedic poets whose words are the true seats of genuine beauty. The mantra reads as follows:

saktumiva titaunā punanto yatra dhīrā manasā vācamakrata I

atrā sakhāyaḥ sakhyā nijānate bhadraișām lakṣmīrnihitādhivāci II (Rgveda, 10.71.2)

In this mantra Sāyana interprets that the men of intuitive wisdom have created refined speech like men cleansing roasted flour in a cribble and the men of scriptural wisdom do comprehend the meaning for their prosperity and the Goddess of good fortune rests in their speech. Here it is suggested that refined speech is the true seat of genuine beauty in poetry that leads to aesthetic enjoyment.

Another mantra denounces the person who is swayed away by the external beauty of poetry and praises the wise in whose heart the inner sense gets revealed. It suggests that poetic content is more valuable than the external form. It reads:

utatvah paśyannadadarśa vācamutatvaḥśrṇvanna śrṇotyenām I

uto tvasmai tanvaì visasre jāyeva patya uśatī suvāsāh II (Rgveda, 10.71.4)

It means that some people see the language but do not use the meaning in their favour; some people with proper hearing do not listen for their benefit; but to some she (the language) exposes the inner beauty completely like a well-dressed (suvāsā) amorous (uśatī) woman to her husband. In the above lines the primary meaning (abhidheyārtha) could not be operative as having eyes and ears one couldn't see or hear respectively. When it is inoperative, the secondary sense (lack of insightfulness) comes connected with the primary sense. Here the purpose (prayojana) of invoking the secondary sense is that the observer and listener of poetry must be a sahrdaya (connoisseur) which is the implied meaning as per the theory of dhvani. Just as a well-dressed wife shows her beauty as a single unit thoroughly and uniformly to her husband, so does the word manifests its beauty to the sahrdaya (connoisseur) instantly. Further it suggests that words used in poetry have a peculiarly different interpretation with regard to the context of description that causes aesthetic enjoyment.

\section{Conclusion}

Rgveda is an embodiment of rhythmic and metrical utterances and is the oldest available literary record of mankind. This magnificent inheritance presupposes at its backdrop a vast oral tradition of literature that enlivened lyrical poetry. Subsequently this Veda influenced the lyrical tradition of poetry and enriched it. It is a fact that the poet-seers were not aware of the modern critical terminologies of literature and also did not posit a formal theoretical text on poetics. However their poetic voice sung the beauty of life through different shades of human emotions and have made many unfamiliar things familiar and personal things universal through the use of evocative imagery culled from the natural and socio-cultural zones of life. In their poetic compositions they have adopted the application of various literary devices like alamkāras (figures of speech), chandas (metrical skills), rasas (poetic sentiments like śrńgāra, vīra, karuna etc.) dhvani (suggestion and the suggestive potency of the language), myths, metaphors, symbols, mystic utterances etc. for the successful achievement of this end. In this way the literary compositions ( $k \bar{a} v y a)$ stood completely different from ordinary communications ( $v \bar{a} r t \bar{a})$ and this influenced the classical Sanskrit rhetoricians to write texts on Sanskrit literary criticism (Alamkāraśāstra). Thus the richness of this vast literature influenced the post-Vedic poets like Vālmikī, Vyāsa, Kālidasa, Bharavi, Magha, Bhațti 
and Bānabhatța to hone their paths of literary art that influenced the literary domain beyond spatiotemporal boundaries.

\section{References}

Apte, V.S. (2007). Saḿskrta-Hindi-Kośa. Delhi: Motilal Banarsidass.

Bhāmaha. (1991). Kāvyālaṁkāra (Ed. \& Tr. P.V. Naganatha Sastry). Delhi: Motilal Banarsidass.

Cassirer, E. (1964). Language and Myth (Tr. Susanne K. Langer). New York: Dover Publications.

Cuddon, J.A. (1998). A Dictionary of Literary Terms and Literary Theory. Delhi: Maya Blackwell Doaba House Publishers.

Griffith, R.T.H. (2004). The Hymns of the Rgveda (Tr. \& Ed. JL Shastri). Delhi: Motilal Banarsidass.

Hillebrandt, A. (1981). Vedic Mythology (Tr. S Rajeswar Sharma). Vol II. Delhi: Motilal Banarsidass.

Jijn̄āsu, B. (1945). Niruktakāra Aur Vedamen Itihāsa. Haryana: Ramlal Kapur Trust.

Kane, P.V. (1995). Sāhityadarpaṇa of Visvanatha Kaviraja. Delhi: Motilal Banarsidass.

Kane, P.V. (2015). History of Sanskrit Poetics, Delhi: Motilal Banarsidass.

Kavirāja, V. (1977). Sahityadarpaṇa (with Vimalā Vyakhyā of Saligrama Sastri). Delhi: Motilal Banarsidass.

Mammața. (2005). Kāryaprakāśa (Ed. \& Tr. Sir Ganganath Jha). Delhi: Bharatiya Vidya Prakasan.

Max Muller, F. (1872). “Comparative Mythology” (extracts). Chips from a German Workshop. Vol. II. New York: Scribner, Armstrong \& Co., 52-141.

Patañjali. (1989). Vyākaraṇa Mahābhāṣya (Ed. Jayasankarlal Tripathy). Vol I. Varanasi: Krishnadas Akademi.

Radhakrishnan, S. (2012). The Principal Upanișads. London: Harper Collins Publishers.

Rgveda. (2011). (Ed. \& Tr. Pundit Ramagovinda Trivedi). Vol. 1-9. Varanasi: Chowkhamba Vidya Bhavan.

Rudrața. (1990). Kāvyālaṁkāra (Ed. \& Tr. Satyadev Choudhury). Delhi: Parimala Publications.

Sastri, P.S. (1998). Rgvedic Aesthetics. Delhi: Bharatiya Vidya Prakashan.

Staal, F. (2008). Discovering the Vedas. India: Penguin Books India.

Yāska. (2009). The Nighantu and the Nirukta (Ed. \& Tr. Laksman Sarup) Part I-III. Delhi: Motilal Banarsidass.

Dr. Bibhudatta Dash is an Assistant Professor in the Department of Humanities \& Social Sciences, Visvesvaraya National Institute of Technology, Nagpur. He has a PhD in Cultural Studies (English Literature) from National Institute of Technology Karnataka, Surathkal. His research interests include studying literatures, cultures, and cinema in interdisciplinary contexts. 